\title{
The Recent Trends of Public Expenditure on Education in Karnataka
}

\section{OPEN ACCESS}

Manuscript ID:

ECO-2020-08032370

Volume: 8

Issue: 3

Month: June

Year: 2020

P-ISSN: 2319-961X

E-ISSN: 2582-0192

Received: 11.03.2020

Accepted: 22.05.2020

Published: 01.06.2020

Citation:

Yadav, Deepmala and Suma Singh. "The Recent Trends of Public Expenditure on Education in Karnataka." Shanlax International Journal of Economics, vol. 8, no. 3, 2020, pp. 75-82.

DOI:

https://doi.org/10.34293/ economics.v8i3.2370

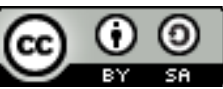

This work is licensed under a Creative Commons Attribution-ShareAlike 4.0 International License

\author{
Deepmala Yadav \\ Research Scholar, Bangalore University, Bengaluru, Karnataka, India \\ https://orcid.org/0000-0003-0863-9397
}

\author{
Suma Singh \\ Associate Professor, Mount Carmel College, Bengaluru, Karnataka, India
}

\begin{abstract}
The very recent and emerging trends of the primary education system in Karnataka show that the enrollments of government schools have come down, Even though the Government expenditure on various schemes to promote Universalisation of Elementary Education (UEE), has been increasing in every consecutive year, these schemes are not fulfilling the Government's aim to improve enrollment and retention rate. On the other hand, private schools have become synonymous with a quality education that is leading to an increase in the number and the enrollments of private schools and is causing the shutdown of government schools. To deal with the problems of providing quality education and keeping the increasing number of private schools in view, the government has involved private sector by passing the bill of Right to Education Act (2009), which in turn has added one more financial responsibility to shoulder for the government in the form of reimbursement to private schools. Reimbursement is a financial burden on government and, at the same time, is not enough to meet the per-child expenditure of (some) private schools. In this changing scenario, the government pattern of spending on elementary education has also changed. Thus, analyzing the pattern and composition of expenditure is crucial to make any government policy feasible, needbased, and result-oriented.
\end{abstract}

Keywords: Government expenditure on elementary education, Educational Profile, Universalisation of Elementary Education (UEE), Sarva Shiksha Abhiyaan (SSA). Education Indicators, Right to Education (RTE) and Reimbursement.

\section{Introduction}

Education is the most important component of the social sector. It is included in the concurrent list of Indian constitution, both Central and state government has the responsibility to maintain quantity, quality, access, and equity in education. Financial resource spends by the government in any sector indicates the importance attached to that sector. The government of Karnataka's overall expenditure on elementary education is almost stagnant for the past few years. However, various changes are taking place as the growing number of private schools, shutting down of Government schools, and initiation of various incentive programs to promote the Universalisation of Elementary Education (UEE). These factors lead to changes in the pattern of expenditure by the Government on Education and thereby necessitating to analyze the trends in the allocation of resources on the different components of the state government budget. Therefore, the present paper will be an attempt to observe the trends of expenditure on education, of Karnataka government on Elementary education, and on various policies to promote UEE.

\section{Review of Literature}

Tilak (1991), explained the trends of plan and non-plan expenditure of education from first to seventh five-year plan and financing of education under a federal structure and mixed economy model of the country. He found that 
during periods of high rates of educational expansion in the fifties and sixties, the share of plan expenditure showed an increase. While non-plan expenditure, of which state governments share the major responsibility, constitute a larger proportion of total expenditure, started increasing post-sixties. Thus, from the financial point of view, education continues to be mainly the responsibility of the state governments. The author suggested that the differential fee structure is more desirable in the Indian context as it is an additional source to finance education.

Tilak (1996) analyzed the expenditure incurred by the parents on education. He found that parents spend large sums of money on acquiring primary education; they pay tuition fee, examination fee, and other fees even in government primary schools, despite the provision of free education. He found that 65 percent of the dropouts were due to poverty; economic factors were more important than any other factor in explaining non-enrolment and dropouts in elementary education in several states in India.

Ramchandran et al. (1997) calculated basic investment requirements in the primary education 17 states of India. They modified the Colclough and Lewin method to calculate investment requirements for universal education. In terms of the total investment on primary education as a percentage of SDP, the commitment required is less than 4 percent of SDP in the states of Delhi, Punjab, Kerala, Maharashtra, Haryana, Tamil Nadu, and Gujarat. Next, come states that needed to commit between 4 and 5 percent of SDP, these include Karnataka, Andhra Pradesh, and West Bengal. Finally, there are the laggard states: Jammu and Kashmir, Orissa, Rajasthan, Uttar Pradesh, Madhya Pradesh, and Bihar. Not surprisingly, these states had to make a huge investment effort (more than 5 percent of SDP) to establish the basic infrastructural requirements for universal primary schooling.

Ramchadran (2009), emphasized the significance of the investment in primary education by the Indian government. It is argued by the other authors that low budget private schools will be helpful in the implementation of the Right to Education ( RTE) and thereby reducing government financial burden. However, private schools are not spreading in remote rural areas, neither ensuring providing quality education. It is, therefore, necessitating for the government to invest in primary education and making EWS (Economically Weaker Section) children able to compete in any sphere.

Dholaka et al. (2010) explained the reasons for spending six percent of the GDP would not be sufficient to provide UEE (Universal Elementary Education). They found that if all the schools are government schools and all teachers are to be paid as per six pay commission reports; the fiscal deficit will be 22 percent of GDP. Private schools deliver comparable better education than that of imparted by government schools at a significantly lowercost They suggested keeping budget constraints and catering to the demand of UEE in view, low-cost private schools, and PPP (Public-Private Partnership) would be a feasible option.

Sengupta and Pal (2012), attempted to look for a new delivery mechanism for the primary education system in India. For that, they used secondary data they collected from the District Information System for Education (DISE) for the Burdwan district of West Bengal. They found that there is a significant relationship between government expenditure on education and the reduction of household burden in terms of financing education.

Gajakosh et al. (2017), examined the primary educational profile of Karnataka State, which is based on the data derived from the DISE and Government Report. They found that plan and nowplan expenditure, revenue, and capital expenditure increased throughout 2010-2017. Progress in the expenditure of infrastructure was noticed in physical infrastructure like the construction of school buildings, separate toilets for boys and girls, and in the supply of uniform, school bags, and reimbursement for fees to unaided private schools.

\section{Objectives}

1. To study the educational profile of Karnataka.

2. To study the trends in public expenditure (plan and non-plan expenditure) in elementary education in Karnataka under SSA.

3. To study government expenditure on various schemes to promote Elementary Education.

4. To put forth suggestions and policy implications. 


\section{Methodology}

The study is based on secondary sources of data. The required data has been obtained from the following sources: Published data of Directorate of Primary Education, Various years' reports of U-DISE, Reports of Sarva Shiksha Abhiyaan (SSA), Karnataka, Reports of Centre of Budget and Government Accountability, Economic and Political Weekly, Books, and News Paper.

\section{Educational Profile of Karnataka}

Karnataka has four Educational Divisions with headquarters at Bangalore, Belgaum, Gulbarga, and Mysore. Besides two divisions - Belgaum and Gulbarga divisions are having Additional Commissionerates for streamlining of administration.

Table 1: Educational Division in Karnataka

\begin{tabular}{|c|l|}
\hline Division & \multicolumn{1}{c|}{ District } \\
\hline \multirow{3}{*}{ Bangalore } & $\begin{array}{l}\text { Bangalore, Bangalore (R), Ramanagar, } \\
\text { Chitradurga, Kolar, Chikkaballapur, } \\
\text { Shimoga, Tumkur and Davanagere. }\end{array}$ \\
\hline
\end{tabular}

\begin{tabular}{|l|l|}
\hline Belgaum & $\begin{array}{l}\text { Belgaum, Bijapur, Bangalkot, Dharwad, } \\
\text { Gadag, Haveri, and Uttara Kannada }\end{array}$ \\
\hline Gulbarga & $\begin{array}{l}\text { Bellary, Bidar, Gulbarga, Raichur and } \\
\text { Koppal, Yadgir }\end{array}$ \\
\hline Mysore & $\begin{array}{l}\text { Chikmagalur, Dakshina Kannada, } \\
\text { Udipi, Hassan, Kodagu, Mandya, } \\
\text { Mysore and Chamarajanagar }\end{array}$ \\
\hline
\end{tabular}

Source: State Educational Profile, Department of Public instruction, Karnataka

There are three kinds of schools in the state, viz., government-run, private aided (financial aid is provided by the government) and private unaided (no financial aid is provided). The primary languages of instruction in most schools are Kannada apart from English, Urdu, and Other languages. The syllabus taught in the schools is by and large the state syllabus (SSLC) defined by the Department of Public Instruction of the Government of Karnataka, and the CBSE, ICSE in case of certain private unaided and KV schools.

Table 2: Number of Elementary Schools in Karnataka

\begin{tabular}{|c|c|c|c|c|c|c|c|c|c|}
\hline \multirow{2}{*}{$\begin{array}{c}\text { Year } \\
\text { Management }\end{array}$} & \multicolumn{3}{|c|}{ 2015-16 } & \multicolumn{3}{|c|}{ 2016-17 } & \multicolumn{3}{|c|}{ 2018-19 } \\
\hline & Rural & Urban & Total & Rural & Urban & Total & Rural & Urban & Total \\
\hline Department of Education & 39174 & 4927 & 44101 & 38882 & 5013 & 43895 & 38496 & 4996 & 43492 \\
\hline $\begin{array}{l}\text { Tribal Social Welfare } \\
\text { Department Schools }\end{array}$ & 549 & 153 & 702 & 560 & 160 & 720 & 861 & 301 & 1162 \\
\hline Local Body & 1 & 25 & 26 & 1 & 24 & 25 & 1 & 25 & 26 \\
\hline Private Aided & 1327 & 1775 & 3099 & 1289 & 1783 & 3072 & 1287 & 1728 & 3015 \\
\hline Private Unaided & 5683 & 7208 & 12891 & 5938 & 7500 & 13438 & 6414 & 8014 & 14428 \\
\hline $\begin{array}{l}\text { Other State Government } \\
\text { Managed Schools }\end{array}$ & 0 & 9 & 9 & 1 & 10 & 11 & 45 & 65 & 305 \\
\hline Centre Govt Schools & 42 & 43 & 85 & 41 & 43 & 84 & 46 & 45 & 91 \\
\hline Unrecognized & 2 & 13 & 15 & 2 & 12 & 14 & 2 & 2 & 4 \\
\hline Total & 46775 & 14153 & 60928 & 46714 & 14545 & 61259 & 47152 & 15176 & 62328 \\
\hline
\end{tabular}

Source: DISE Karnataka State Education Report 2015-16, 2016-17, and 2018-19.

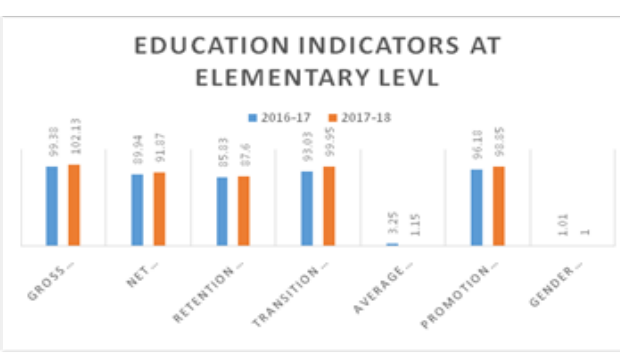

Table 3: Education Indicators at Elementary Level

\begin{tabular}{|l|c|c|}
\hline \multirow{2}{*}{\multicolumn{1}{c|}{ Indicators }} & \multicolumn{2}{c|}{ Year } \\
\cline { 2 - 3 } & $\mathbf{2 0 1 5 - 1 6}$ & $\mathbf{2 0 1 8 - 1 9}$ \\
\hline Gross Enrolment Ratio & 99.38 & 102.13 \\
\hline Net Enrolment Ratio & 89.94 & 91.87 \\
\hline Retention Rate & 85.83 & 87.6 \\
\hline Transition Rate & 93.03 & 99.95 \\
\hline Average annual Dropout & 3.25 & 1.15 \\
\hline
\end{tabular}




\begin{tabular}{|l|c|c|}
\hline Promotion Rate & 96.18 & 98.85 \\
\hline Gender Parity Index & 1.01 & 1.0 \\
\hline
\end{tabular}

Source: U-DISE Report, Karnataka 2015-16 and 2018-19.

In 2018-19 total number of schools was 15949 out of which 3801 was private aided,6746 was private unaided,4696 was under the Department of Education, 42 was under the local body. The Gross enrolment ratio at the elementary level was 102.13 percent and at the secondary level was 104.79 percent. All education-related indicators depict improvement.

\section{Karnataka Government Expenditure on Education (Plan and Non-Plan Expenditure)}

The educational budget in India contains two parts - plan (also called developmental) and non-plan (also called committed) expenditures. The plan expenditure is mainly for development purposes such as the building of new schools or the introduction of a new program in a school. The nonplan expenditure is generally for the maintenance of on-going programs as well as of buildings, furniture, and equipment. One would have thought that this distinction between plan and non-plan expenditure corresponds to recurring and capital expenditure. But this is not the case. There can be both recurring and capital expenditure both in the plan expenditure or in the non-plan expenditure (Unesco: 1984). There is scope for enough debate, if not confusion, on the scope of the plan and non-plan expenditure on education. For example, the opening of a school may be treated as plan expenditure. Still, if all the facilities are not provided in the same plan itself, then it can be argued that these facilities should be treated as committed or non-plan expenditure. Let us look at the relative shares of these categories. (Tilak, 1991).

Table 4: Karnataka Government Expenditure on Elementary Education

\begin{tabular}{|c|c|c|c|c|c|c|}
\hline Year & Plan & $\begin{array}{c}\text { Percentage } \\
\text { of total } \\
\text { expenditure }\end{array}$ & Non Plan & $\begin{array}{c}\text { Percentage } \\
\text { of total } \\
\text { expenditure }\end{array}$ & Total & $\begin{array}{c}\text { Percentage of total } \\
\text { exp on education }\end{array}$ \\
\hline $2010-11$ & 90041.24 & 17.76 & 416989.72 & 82.24 & 507030.96 & 51.76 \\
\hline $2011-12$ & 92553.16 & 16.47 & 460306.86 & 83.26 & 552860.02 & 52.16 \\
\hline $2012-13$ & 271129.35 & 32.22 & 570465.04 & 67.78 & 841594.39 & 66.11 \\
\hline $2013-14$ & 336262.15 & 35.71 & 605531.84 & 64.29 & 941793.99 & 62.14 \\
\hline $2014-15$ & 376269.67 & 35.59 & 681147.49 & 64.41 & 1057417.06 & 54.15 \\
\hline $2015-16$ & 296042.00 & 31.22 & 652114.00 & 68.78 & 948156.00 & 60.95 \\
\hline $2016-17$ & 412212.00 & 41.87 & 572130.00 & 58.13 & 984342.00 & 53.33 \\
\hline
\end{tabular}

Source: Department of School Education, Government of Karnataka, Annual Budget of Elementary Education, various years.

The trends of any government expenditure on education show that the non-plan expenditure accounted for a larger share of total expenditure. The initial period of educational expansions necessitated the creation of a large number of infrastructural facilities in terms of opening new schools and the provisions of other inputs that come under the category of development expenditure. (Tilak,1991) However, afterward, the government spends more on non-plan expenditure. The Same is the case with Karnataka. Trends of Karnataka Government expenditure are seen in table 4; the government is incurring more expenditure on non-plan expenditure. However, from the year 2012-13 sudden increase was seen in plan-expenditure due to the effective implementation of the Right to Education (RTE). Overall expenditure on elementary education was declined in the year 2015-16 because the dropout rate of students in the government school is increasing. The government of Karnataka decided to shut down the schools due to inadequate strength. Parents prefer private schools for their wards to get a quality education. Government schools are suffering from teacher absenteeism and poor infrastructure.

\section{Budgetary Allocation on Incentive Programmes to Promote Elementary Education}

The Government of Karnataka launched a various important programs to promote elementary education. Brief description of them are as follows: 


\section{- Distribution of Free Uniforms and Shoes}

During 2015-16, One set of uniforms and shoes are provided to all children from 1st standard to 10th standard studying in Government Primary High Schools. For the implementation of this scheme in the year 2012-13, 800 lakhs and 2013-14 704 lakhs of the budget was allocated.

\section{- Distribution of School Bags and Notebooks}

To reduce the dropout rate of SC/ST Boys \& Girls in Government Primary Schools, good quality school bags were given to those who are studying in 1,3,5,7 std in Government Primary Schools. Notebooks were supplied to each SC/ST Children who are studying in 1,2 46 Std. During 2015-16 Rs.1521.00 lakhs of Budget was provided for this purpose under the State sector scheme.

\section{- E-Governance}

E-technology has been widely in use in the department of instruction. With the help of Edusat Satellite Facility, teleconferencing is being used to a large extent, to impart training to teachers and field level officers, apart from using this medium for periodical progress review.Rs.100.00 lakhs have been provided for E-Governance to purchase required Computer Hardware, Software and to purchase Computer and accessories for the office of DDPI's (Deputy Director of Public Instruction) offices and also for maintenance of computer supplied to DDPI and BEO (Block Education Officer) offices in 201516, which was 50,000 lakhs in the year 2013-14.

\section{- Sports and Language Development}

Rs.100.00 lakhs in the year 2013-14 and Rs. 300.00 lakhs in 2015-16 have been provided to conduct Taluk, District \& State Level Games and to purchase Sports materials, and to provide playground facilities. Provision of Rs 24.00 lakhs in 2013-14, and35.00 lakhs in 2014-15 have been made for the improvement of educational activities of Urdu \& Linguistic Minorities Directorate and Office Automation.

\section{- Pratibha Karanji Programme}

Prathiba Karanji is an innovative program where Cultural and literary competitions are conducted at cluster, block, and District and State levels.Rs.470.00 lakhs have been provided for conducting Pratibha Karanji Programme.

\section{- Akshara Dasoha}

Akshara Dasoha or Mid-day program was implemented in 7 educationally and economically backward north-eastern district of the state during 2001-02. Under this program, hot cooked meals to all children studying in classes 1 to 10th standard in 10 government and aided schools were provided to improve enrollment, retention rates and to improve child health. During the year 2013-14, 134044.39 lakhs, and for the year 2015-16, 153364.70 lakhs have been allocated to this program.

\section{- Pancha Soulabhya}

Panch saulabhya aims to maintain the provision of toilets and drinking water in Primary and High schools of the state. During the year 201516 Rs.400.00 Lakhs, and in the year 2013-14, 706.66 lakhs of Budget have been allocated to this Programme.

\section{- Construction and Repairs of Classrooms}

During 2015-16 Under the state Sector (NonPlan) Rs.2382.00 lakhs of Budget was provided for Primary/Secondary Schools Maintenance and repairs while the amount was 1148.80 lakhs in the year 2013-14.

\section{Sarva Shiksha Abhiyan (SSA), National} Programme of Education for Girls at Elementary Level (NPEGEL), Kasturba Gandhi Balika Vidyalaya (KGBV)

Sarva Shiksha Abhiyan (SSA), Mission was launched during the year 2001-02 by the Government of India. SSA is an umbrella program that covers all the preceding government interventions. In 1993-94 District Primary Education Program (DPEP) was a huge initiative in terms of the area it covered and the amount spent by the government however, it could not succeed in bringing quality and inclusive education. Sarva Shiksha Abhiyan (SSA) is a timebound project of the Government of India to achieve the Universalisation of Elementary Education (UEE). Within the ambit of SSA, a special thrust was also brought on girls' education through the National Programme of Education for Girls at Elementary Level (NPEGEL) launched in 2003, and Kasturba Gandhi Balika Vidyalaya in 2005. The program aims at development and promotes facilities to provide access to elementary education 
for girls through community mobilization and cluster development. Community mobilization activities include the formation of the group like Mother Teacher Associations (MTA), Women Motivator Groups (WMG), MahilaSamakhya (MS) to follow up attendance, enrollment, and retention. Kasturba
Gandhi Balika Vidyalaya (KGBV) is a scheme launched in July 2004, setting up residential schools at upper primary level for girls belonging to the Schedule Caste (SC), Schedule Tribes (ST), Other Backward Class (OBC) and minority communities.

Table 5: Financial Progress Of SSA, NPEGL, AND KGBV

\begin{tabular}{|l|c|c|c|c|c|}
\hline \multicolumn{1}{|c|}{ Year } & AWP\&B & Goi Share & State Share & Expenditure & $\begin{array}{c}\text { \% Against } \\
\text { Allocation }\end{array}$ \\
\hline $2001-02$ & 6022.22 & 85 & 15 & 132.43 & 2.20 \\
\hline $2002-03$ & 11465.58 & 75 & 25 & 5209.37 & 49.48 \\
\hline $2003-04$ (SSA-NPEGL) & 31407.82 & 75 & 25 & 16050.48 & 51.01 \\
\hline $2004-05$ SSA-NPEGL, KGVB & 41659.91 & 75 & 25 & 31651.94 & 70.85 \\
\hline $2005-06$ & 44530.17 & 75 & 25 & 35101.94 & 79.10 \\
\hline $2006-07$ & 75968.75 & 75 & 25 & 53495.81 & 70.51 \\
\hline $2007-08$ & 60745.00 & 65 & 35 & 74359.84 & 105.59 \\
\hline $2008-09$ & 96042.74 & 65 & 35 & 86815.68 & 90.30 \\
\hline $2009-10$ & 96104.08 & 60 & 40 & 79491.43 & 82.71 \\
\hline $2010-11$ & 151190.86 & 65 & 35 & 105071.82 & 69.50 \\
\hline $2011-12$ & 145869.76 & 65 & 35 & 116990.06 & 80.20 \\
\hline $2012-13$ & 206428.30 & 65 & 35 & 154707.35 & 74.97 \\
\hline $2013-14$ & 118216.064 & 65 & 35 & 116684.696 & 98.70 \\
\hline $2014-15^{*}$ & 1340 crore & & & & \\
\hline $2015-16^{*}$ & 1546 crore & & & & \\
\hline
\end{tabular}

Source: http://ssakarnataka.gov.in/pdfs/aboutus/edn_profile_state.pdf

*Accountability Initiative, State Report Card, Centre for Policy Research

Due to the launch of NPEGL and KGBV, the allocation for education was increased amounted to Rs 31407.82 and 41659.91 in the year 2003-04 and 2005-05, respectively, as shown in table-5. The allocation of Rs.1511.49 crores during 201011 included Rs. 323.00 crores released for activities related to RTE implementation. However, this allocated grant for RTE implementation could not be received as RTE rules were yet to be notified. Approved allocations for Sarva Shiksha Abhiyan (SSA), (including state shares) increased by 15 percent from 1,340 crores in FY 2014-15 to 1,546 crores in FY 2015-16. The actual release of funds has also been consistently lower than recommended by AWP\&B. Per child expenditure for SSA, in Karnataka, is Rs 5111, which is lower than that of Punjab and Uttar Pradesh.

\section{Reimbursement For Private School}

For the academic year 2018-19, the reimbursement amount payable by the state government to private unaided schools for accommodating underprivileged children for class one and preschool will be Rs 11,848 and Rs 5,924 respectively for Karnataka. Government reimbursement is way lower than the actual expenses incurred by private unaided schools. There is a variation in the cost structure of the different types of schools; International/Residential schools have to spend a lot while low budget private schools incur low expenditure. For some schools, the reimbursement amount is not enough to cover the cost.

\section{Findings}

- Government schools are increasingly being shut down or merged in Karnataka. Data shows that schools under the Department of Education, and 
private aided are being shut down more in rural areas.

- Private schools are rapidly increasing both in urban and rural areas. Parents are seeking quality education for their ward. If financial constraint is removed, people will choose private schools even in rural areas, where education in public school is almost free. Government schools are suffering from poor infrastructure, teacher absenteeism, no accountability for teaching and learning.

- Non-plan expenditure is the larger proportion of State Government expenditure. Under non-plan expenditure, Karnataka Government spends on maintenance and repairs of the school buildings, constructions of classrooms, and appointment of nursery teachers. The Major components of non-plan expenditure are UEE, SSA, and remuneration to the contract teachers and school teachers.

- Government expenditure on various incentive programs has increased. Since enrollment in government schools and a number of schools are coming down, these programs have not affected much. They are not fulfilling the Government's aim to improve enrolment and retention rates.

- As compared to other schemes, Karnataka government is spending more on Mid-day Meal (Akshara Dashoha), despite that there have been cases of children falling sick after eating food that is provided under the scheme.

- SSA has been continuously getting less financial support, from the Government, than what has been recommended by AWP\&B.

- Significant improvement has been noticed in all education-related indicators.

\section{Suggestions}

Following suggestions can be given to improve the status;

- The Efficiency of government expenditure can be increased by improving the infrastructure of the schools.

- There should be some independent body that can monitor the quality of the schools throughout the year.

- Quality in education can be brought by bringing accountability for teachers' absenteeism.

- In addition to that, the Reimbursement amount for private schools should be customized according to the different cost structures of different types of schools.

- Per student allocation under SSA is lower than that of other states, which needs to be scaled up. More government schools need to be set up in the urban area to help urban poor.

\section{Conclusion}

Karnataka has made considerable progress in the past few decades in terms of enrolment, infrastructure, number of schools, and allocation of resources to promote universalization of education. For that matter, various programs and policies have been launched by the Government of Karnataka. Consequently, substantial positive progress has been noticed in various education indicators in terms of gender parity, the inclusion of Out of the School Children (OOSC). However, Government schools have failed in providing quality education. As a result, privatization has started hovering even in the education sector and turning it into a profitmaking industry. Government efforts toward providing quality education should not be evaluated by the amount of money it spends. For proper implementation of the schemes, accountability and efficient mechanism are required.

\section{References}

Bhattacharjee, Sanchayan. Ten years of RTE act: Revisiting Achievements and Examining Gaps, Observer Research Foundation, Issue Brief No. 304, 2019.

Biswas, A. and S.P. Agrawal. Development of Education in India: A Historical Survey of Educational Documents before and after Independence. Concept Publishing Company, 1986.

Bose, Sukanya, et al. "What Does the Right to Education need to Achieve?." Economic and Political Weekly, vol. 54, no. 18, 2019

Draft National Educational Policy 2019, MHRD, 2019.

Education for All: Towards Quality with Equity, NUEPA, Government of India, 2014. 
Education in Karnataka State, 2011-12, A State Level and District Wise Analytical Report, Sarva Shiksha Abhiyan - Karnataka, 2012.

Gajakosh, R.S. and Gangshetty, R.V. Performance of Government Expenditure on Primary Education in State of Karnataka, Edupedia Publications Pvt Ltd., 2017.

Guidelines for Implementation of the National Programme for Education of Girls at Elementary Level, Ministry of Human Resource Development, New Delhi, 2003.

Hingorani, D.K. "Education in India Before and After Independence." The Educational Forum, vol. 19, no. 2, 1955, pp. 217-225.

Jain, P.S. and Dholakia H.R. "Right to Education Act and Public-Private Partnership." Economic and Political Weekly, vol. 45, no. 8, 2010, pp. $78-80$.

Karthik, Dinne. Unpacked: The black box of Indian School Education Reform, Centre for Civil Society, 2015.

Kundu, P. Samagra Shiksha Abhiyaan (SMSA) From Girls' Education Lens: An Initial Analysis, Centre for Budgeting and Governance Accountability (CBGA), 2019.

Kundu, Protiva, et al. Public Financing of School Education; A Fact Sheet, Centre for Budget and Governance Accountability (CBGA), 2016.

Manual for District Level Functionaries, Sarva Shiksha Abhiyaan, 2017.

Sahgal, Gayathri. Empowering schools and school management committees (SMCs): Unpacking decision-making in India's schools, 2012.

Saikia, S. History of Education in India, Mani Manik Prakash, 1998.

Sengupta, Atanu and Naibedya Prasun Pal. "Assessing the Primary Schools - A Multi- dimensional Approach: A School Level Analysis based on Indian Data." International Journal of Educational Development, vol. 32, no. 2, 2012, pp. 264-272.

Soni, R.B.L. Status of Implementation of RTE Act2009 in Context of Disadvantaged Children at Elementary Stage, NCERT, 2013.

Sripati, Vijayashri and Arun K. Thiruvengadam. "India: Constitutional Amendment making the Right to Education a Fundamental Right." International Journal of Constitutional Law, vol. 2, no. 1, 2004, pp. 148-158.

Swaminathan, Mathura, et al. "Investment Gaps in Primary Education - A Statewise Study." Economic and Political Weekly, vol. 32, no. 1-2, 1997.

Taneja, Anjela, et al. Status of Implementation of the Right of Children to Free and Compulsory Education Act, 2009 (2017-18), Report by RTE Forum, 2018.

Taneja, Anjela, et al. The Right of Children to Free and Compulsory Education Act, 2009, Report by the RTE Forum, 2014.

Tilak, B.G. "How Free is 'Free' Primary Education in India." Economic and Political Weekly, vol. 31, no. 5, 1996.

Varghese, N.V. and Jandhyala B.G. Tilak. Financing the Education of India. International Institute for Educational Planning, UNESCO, 1991.

Venkatanarayanan, S. "Tracing the Genealogy of Elementary Education Policy in India Till Independence." Sage Open, 2013, pp. 1-10.

Verma, Kanika, et al. The Bright Spots: Status of Social inclusion through RTE Section 12(1) (c) 2018, Indus Action, 2018.

Vil'anilam, J.V. "Development of Education in India: 1947-2012." Yojana, vol. 56, 2012, pp. 28-33.

\section{Author Details}

Deepmala Yadav, Research Scholar, Bangalore University, Bengaluru, Karnataka, India

Email ID: deepay2019@gmail.com.

Dr. Suma Singh, Associate Professor, Mount Carmel College, Bengaluru, Karnataka, India 